\title{
Histopathological findings in human choroidal melanomas after transpupillary thermotherapy
}

\author{
J G Journée-de Korver, J A Oosterhuis, D de Wolff-Rouendaal, H Kemme
}

\begin{abstract}
Aims-The effect of transpupillary thermotherapy (TTT) on human choroidal melanomas was investigated by means of histopathology.

Methods-Before enucleation TTT was performed in 11 eyes with a xenon arc photocoagulator with a red filter or a diode laser at $810 \mathrm{~nm}$. The exposure time was 1 minute; the estimated temperature at the top of the tumour was about $65^{\circ} \mathrm{C}$.

Results-Seven of 11 tumours developed necrosis to a maximum depth of $3.9 \mathrm{~mm}$ with a sharp demarcation between the necrotic and the viable part of the tumour. The depth correlated with penetration of heat into the tumour. Scattered small haemorrhages in the transitional zone between the necrotic and the viable part of the tumour were observed in three eyes but large haemorrhages were absent. Ocular media were not affected owing to the low rate of absorption of radiation at $810 \mathrm{~nm}$. TTT did not cause significant scleral damage. Intrascleral tumour cells with a viable appearance were observed in one eye, where the tumour was almost totally necrotic.

Conclusion-Results show that TTT has potential as a conservative therapeutic treatment for choroidal melanomas. (Br F Ophthalmol 1997;81:234-239)
\end{abstract}

Enucleation as treatment of choroidal melanomas is partly replaced by radiotherapy with charged particles or brachytherapy with ruthenium-106 or iodine-125. Irradiation is associated with failures and complications since approximately $50 \%$ of eyes develop late complications after brachytherapy. ${ }^{2}$

Hyperthermia is used to treat malignant tumours, including melanomas, because of its synergistic action with radiation. ${ }^{3-5}$ It is generally performed at tumour temperatures below $43^{\circ} \mathrm{C}$ and exposure times of 30 minutes or more; under these conditions it has limited potential as sole means of destroying tumour cells but it does enhance the effect of radiotherapy. For treatment of choroidal melanomas hyperthermia is applied by means of microwave, ${ }^{6-9}$ localised current field, ${ }^{1011}$ ultrasound, ${ }^{12-14}$ and ferromagnetic thermoseeds. ${ }^{15}$ With these trans-scleral techniques hyperthermia does not cause permanent damage to normal tissue. ${ }^{1617}$
Hyperthermia at a tumour temperature of $45^{\circ} \mathrm{C}$ or more can be designated as thermotherapy since after application for 1 minute it exerts an irreversible destructive effect on cells for which it does not require additional radiotherapy or cytostatic drug therapy. ${ }^{18-20}$ The application of thermotherapy at more than $45^{\circ} \mathrm{C}$ in clinical oncology is restricted since it affects both malignant and normal cells. In ophthalmology, however, thermotherapy by means of transpupillary infrared radiation can be used to treat choroidal melanomas ${ }^{19}$ because the rate of absorption at $810 \mathrm{~nm}$ is low for clear ocular media. ${ }^{21}$

This paper deals with the histopathological findings in human choroidal melanomas enucleated after transpupillary thermotherapy.

\section{Material and methods}

Eleven patients with large choroidal melanomas underwent transpupillary thermotherapy (TTT) by infrared irradiation before enucleation. We did not aim for total destruction of the tumour. Permission for the investigation was given by the medical ethics committee of Leiden University Medical Centre and informed consent was obtained from each patient after full explanation of the procedure. Before treatment the pupil was dilated with phenylephrine hydrochloride $5 \%$ and tropicamide $0.25 \%$ eyedrops. Immobilisation of the eye and anaesthesia to make the treatment painless were achieved with a retrobulbar injection of $2 \mathrm{ml}$ prilocaine hydrochloride $2 \%$ (Citanest).

TTT was performed in four patients with a modified xenon photocoagulator (Zeiss, Oberkochen, Germany) with a red filter permitting $85 \%$ transmission between 780 and $880 \mathrm{~nm} .{ }^{22}$ In seven patients we used a continuous wave diode laser (Nidek, Tokyo, Japan) which produced radiation at $810 \mathrm{~nm}$ via a handheld fibre in front of the eye. Both methods yield a beam diameter on the surface of the tumour of $2-4.5 \mathrm{~mm}$. For the laser lens we used the panfunduscope (Rodenstock, Munich, Germany) or the Mainster lens (Mainster, Ocular Instruments, Bellevue, WA, USA). Because of variations in beam diameter the energy output was calculated in $\mathrm{W} / \mathrm{cm}^{2}$ on the target area. We started the irradiation at the relatively low level of $3 \mathrm{~W} / \mathrm{cm}^{2}$ and an exposure time of 1 minute. In the absence of an ophthalmoscopic effect we increased the energy level stepwise until the tumour exhibited a greyish 
discoloration as a result of tissue oedema developing during the 1 minute exposure. The maximum irradiance was $19 \mathrm{~W} / \mathrm{cm}^{2}$ for the xenon photocoagulator and $12 \mathrm{~W} / \mathrm{cm}^{2}$ for the diode laser. The interval between TTT and enucleation was 1 day in three patients, 2 days in five patients, and 3, 4, and 10 days, respectively, in the other three patients. After enucleation the eyes were fixed in buffered formaldehyde $(10 \%)$, dehydrated in a series of alcohols and embedded in celloidin. Serial sections $17 \mu \mathrm{m}$ thick were cut in a plane parallel to the light beam (Jung microtome, Heidelberg, Germany). Haematoxylin and eosin stained and some depigmented $\left(\mathrm{KMnO}_{4}\right)$ sections were examined by light microscopy. Depth of tumour necrosis was measured with the aid of a grid.

\section{Results}

Data on tumour height and pigmentation, equipment used for TTT, diameter of the radiation beam, irradiance, radiant exposure, time interval between TTT and enucleation, and depth of tumour necrosis are summarised in Table 1.

Tumour necrosis varying in depth between 1.3 and $3.9 \mathrm{~mm}$ was observed in seven of 11 melanomas. One eye was treated by xenon irradiation and enucleated 48 hours after TTT, the other six were treated with a diode laser and enucleated 48 hours to 10 days after TTT. The demarcation between the necrotic and viable parts of the tumour was sharply defined both in depth and in lateral direction (Figs 1-5). In two eyes (Nos 6 and 10) cones of necrotic tissue in between segments of viable tumour tissue were observed (Fig 5).

Four tumours (Nos 5, 8, 10, 11) contained two layers of necrosis, each with a different appearance of cell death (Figs 2A, 4A, 5). A superficial layer $0.7-2.2 \mathrm{~mm}$ contained tumour cells with shrunken nuclei, most of them without nucleoli, and loss of cytoplasm. All tumour vessels in this area were dilated and occluded by thrombi; some contained red blood cell ghosts (Fig 2B). Haemorrhages were absent.

The superficial layer was surrounded by a $0.7-1.9 \mathrm{~mm}$ zone of nuclear debris without cytoplasm and widened intercellular spaces. Also in this area vessels were occluded and even large vessels had not leaked erythrocytes
(Fig 2D). In two patients (Nos 6, 11) some haemorrhages were observed in the peripheral part of the heat damaged area (Fig 4A).

A small transitional area of $0.15-0.7 \mathrm{~mm}$ could be seen between the necrotic and the viable part of the tumour with or without scattered small haemorrhages (Fig 2C).

Scleral damage was insignificant when the tumour necrosis bordered on the sclera. Heat penetration had caused some oedema but the scleral collagen retained its lamellar structure; sclerocytes had disappeared in this area but intrascleral tumour cells were present (Fig 4B).

In eight eyes retinal necrosis and atrophy in the TTT treated area were clearly separated from the surrounding normal retina (Fig 1A, $2 \mathrm{~A}, 3,4 \mathrm{~A})$.

There were no signs of inflammation either in the tumour or in the pathway of the radiation beam through the eye. Ocular structures in the pathway of the radiation beam remained normal except for a local anterior subcapsular cataract in three patients (Nos 5, $7,8)$; it had developed where the laser beam from the handheld fibre had accidentally touched the iris.

Among the three patients treated with the xenon equipment a thermotherapy effect was not observed in the first two eyes enucleated 24 hours after TTT. The tumour in the third patient showed only some pyknotic tumour cells and dilated blood vessels in the most superficial layers of the tumour.

Histopathological examination of the tumour from patient 9, who was treated with ruthenium-106 brachytherapy 1 year before TTT and enucleated 22 hours after TTT, revealed pyknotic tumour cells throughout the tumour, some dilated blood vessels with thrombi and areas with viable tumour cells. Differentiation between the effect caused by irradiation and that caused by heat was not possible.

\section{Discussion}

Transpupillary thermotherapy (TTT) resulted in tumour necrosis to a maximum depth of 3.9 $\mathrm{mm}$ with a sharp demarcation between damaged and viable parts of the tumour; it did not affect the normal ocular structures.

The heat induced lesions are comparable with those found in hamster Greene melanomas implanted in the eyes of rabbits and

Table 1 Heat induced tumour necrosis in patients with choroidal melanomas treated with transpupillary thermotherapy (TTT) before enucleation

\begin{tabular}{|c|c|c|c|c|c|c|c|c|c|}
\hline \multirow[b]{2}{*}{$\begin{array}{l}\text { Patient } \\
\text { No }\end{array}$} & \multicolumn{2}{|l|}{ Tumour } & \multirow[b]{2}{*}{$\begin{array}{l}\text { Tumour } \\
\text { pigment }\end{array}$} & \multirow[b]{2}{*}{ Equipment } & \multirow[b]{2}{*}{$\begin{array}{l}\text { Beam } \theta \\
(\mathrm{mm})\end{array}$} & \multirow[b]{2}{*}{$\begin{array}{l}\text { Irradiance } \\
\left(W / \mathrm{cm}^{2}\right)\end{array}$} & \multirow[b]{2}{*}{$\begin{array}{l}\text { Radiant exposure } \\
\left(\mathfrak{F} / \mathrm{cm}^{2}\right)\end{array}$} & \multirow[b]{2}{*}{$\begin{array}{l}\text { Enucleation } \\
\text { after TTT } \\
\text { (hours) }\end{array}$} & \multirow[b]{2}{*}{$\begin{array}{l}\text { Depth of } \\
\text { necrosis }\end{array}$} \\
\hline & $\begin{array}{l}\text { Height } \\
(\mathrm{mm})\end{array}$ & $\begin{array}{l}\theta \\
(\mathrm{mm})\end{array}$ & & & & & & & \\
\hline 1 & 9 & 15 & + & Xenon & 2.4 & $4-10$ & 7300 & 24 & - \\
\hline 2 & 10 & 13 & $+/-$ & Xenon & & & & 24 & - \\
\hline 3 & 9 & 11 & $+/-$ & Xenon & $2+4.5$ & $2-19$ & 11000 & 48 & —* \\
\hline 4 & 6 & 12 & + & Xenon & 2.5 & $7-19$ & 11100 & 48 & 1.3 \\
\hline 5 & 9 & 13 & + & Diode & 3.5 & $1-8$ & 4200 & 48 & 3.9 \\
\hline 6 & 5.3 & 11 & + & Diode & 3 & 9 & 3200 & 48 & 1.5 \\
\hline 7 & 7.3 & 11 & + & Diode & 4 & $7-10$ & 3600 & 72 & 3.4 \\
\hline 8 & 14 & $>24$ & ++ & Diode & 3 & $7-12.5$ & 6200 & 48 & 3 \\
\hline 9 & 4.4 & 12 & +++ & Diode & 3.4 & $8-14$ & 5600 & 22 & —* \\
\hline 10 & 11 & $>15$ & ++ & Diode & 3.3 & 10 & 4000 & 96 & 3.4 \\
\hline 11 & 2 & 13.2 & ++ & Diode & 3.4 & $9-11.5$ & 3150 & 240 & 2 \\
\hline
\end{tabular}

${ }^{\star}$ Minimal effect. 

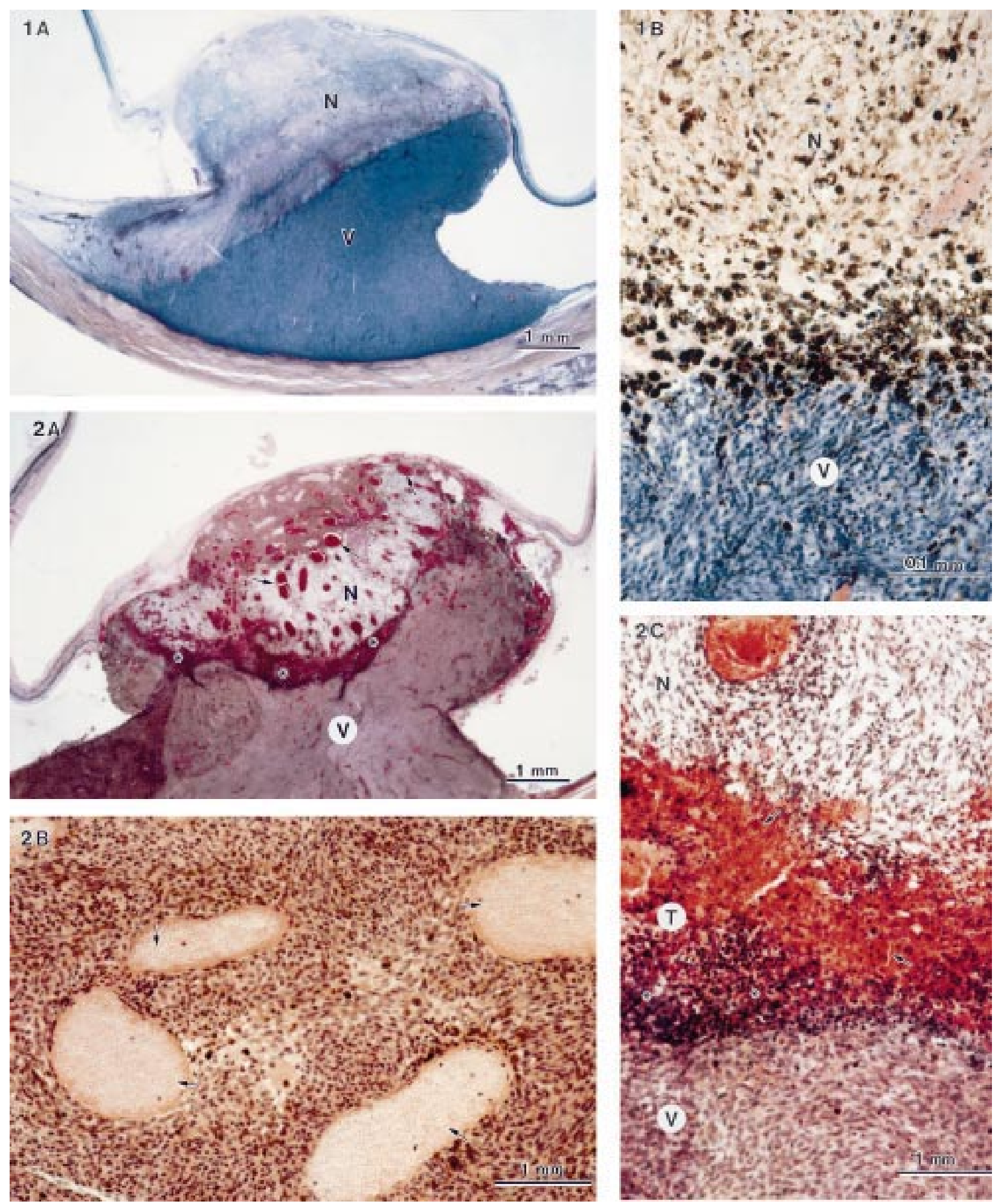

Figure 1 (A) Patient 7. Depigmented haematoxylin and eosin stained section showing transpupillary thermotherapy induced necrosis $(N)$ in a choroidal melanoma with a depth of $3.4 \mathrm{~mm}$, sharply demarcated from the viable part $(V)$ of the tumour without haemorrhages. Retinal necrosis and atrophy correspond with the area of necrosis of the tumour. (B) Haematoxylin and eosin stained section of the same eye as shown in $(A)$ at higher magnification. Sharp demarcation between necrotic $(N)$ and viable $(V)$ parts of the melanoma without haemorrhages.

Figure 2 (A) Patient 5. Transpupillary thermotherapy induced necrosis $(N)$ with a depth of $3.9 \mathrm{~mm}$ in a choroidal melanoma sharply demarcated from the viable part $(V)$ of the tumour. Different histological features of cell damage in the superficial and deeper lavers of the necrotic zone. All tumour vessels in this area are dilated and occluded by thrombi. Scattered small haemorrhages are present in the transitional zone between the necrotic and the viable part of the tumour (asterisks). Retinal necrosis is seen in the target area. $(B)$ Detail of $(A)$. Blood vessels in the most superficial layer contain red blood cell ghosts (arrow). $(C)$ Detail of $(A)$. The transition area $(T)$ between necrotic $(N)$ and viable $(V)$ parts of the tumour contains scattered haemorrhages (arrows) and tumour cells with dense pyknotic nuclei (asterisks). (D) Histological section of a different part of the tumour as shown in $(A)$. Large dilated blood vessel crossing the area of necrosis became thrombotic but did not bleed. (V) viable part, (N) necrotic part of the tumour, (bv) blood vessel. 

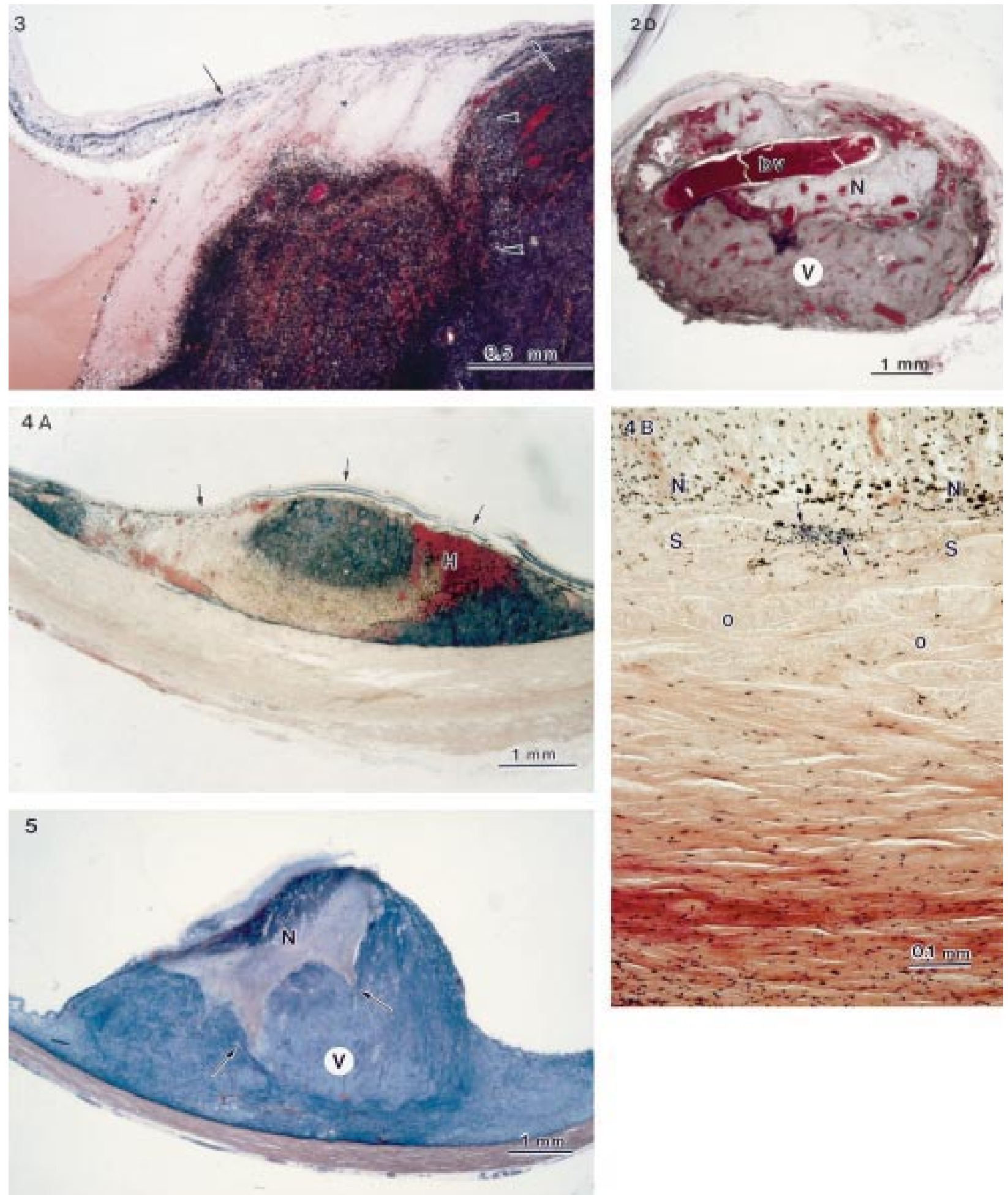

Figure 3 Patient 4. Sharp lateral demarcation of transpupillary thermotherapy induced effect in a melanoma (arrowhead), and in retinal (arrows) and subretinal exudate (asterisks).

Figure 4 (A) Patient 11. Transpupillary thermotherapy induced tumour necrosis with a depth of $2 \mathrm{~mm}$. Different histological features of cell damage in the superficial layers of the tumour. Haemorrhages $(H)$ developed along the periphery of the necrotic part of the tumour. Retinal necrosis is present in the target area (arrows). (B) Same patient as in (A). Necrotic tumour borders on the sclera. The inner scleral layers are oedematous (O); the lamellar structure of the collagen remained intact. Intrascleral tumour cells (arrows) have a viable appearance but sclerocytes in this area have disappeared. Figure 5 Patient 10. Depigmented haematoxylin and eosin stained section of the tumour. Different histological features of transpupillary thermotherapy induced cell damage in the superficial and deeper layers of the tumour. Irregular but sharp demarcation of the area of necrosis as cones of necrotic tissue (arrows) are located in between segments of viable tumour tissue. (V) viable part, $(N)$ necrotic part of the tumour. 


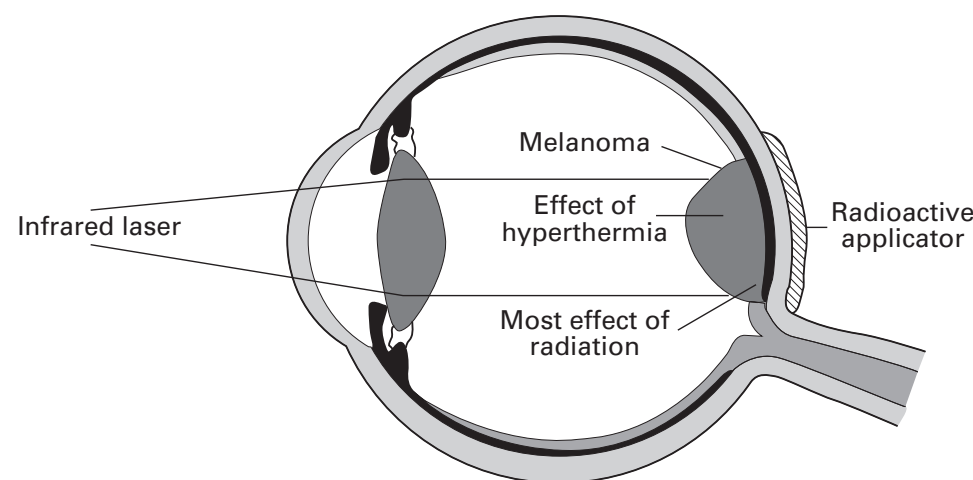

Figure 6 Schematic drawing of 'sandwich therapy', transpupillary thermotherapy being most effective at the top of the tumour, and brachytherapy at the base of the tumour.

subcutaneously in hamsters. ${ }^{18-23}$ The heat induced necrosis is caused mainly by a direct cytotoxic effect, not by ischaemia as is evident from our light and electron microscopic findings after thermotherapy. ${ }^{24}$

Thrombosis of tumour vessels may explain the low tendency to bleed, which was also observed clinically and in animal experiments. ${ }^{18-23}$

The transition between the necrotic and the viable part of the tumour was about perpendicular to the direction of the radiation beam. The rather sharp demarcation may be attributed to a steep decrease in temperature in the tumour. During TTT the maximum temperature at the apex of the tumour will be about $65^{\circ} \mathrm{C}$, at or just below the threshold for an ophthalmoscopically visible coagulation effect. ${ }^{2526}$ The temperature in the demarcation zone is estimated to be about $45^{\circ} \mathrm{C}$, the lowest temperature which causes irreversible tissue damage. ${ }^{1427}$ Thus the decrease in temperature in a tumour with necrosis measuring $3 \mathrm{~mm}$ in depth will be about $5^{\circ} \mathrm{C}$ per mm tumour tissue, as was also calculated by Svaasand (personal communication).

Bleaching of erythrocytes in the most superficial tumour vessels is caused by heat damage during stasis of the circulation caused by thrombosis developing during TTT (Fig 2B). The temperature in these vessels was increased above $57^{\circ} \mathrm{C}$, the critical clotting temperature where fibrinogen is converted into fibrin. ${ }^{28}$

Signs of tumour cell damage were absent in one patient (No 1) despite a rather high irradiance of $4-10 \mathrm{~W} / \mathrm{cm}^{2}$ and radiant exposure of $7300 \mathrm{~J} / \mathrm{cm}^{2}$; in another patient (No 3) an even higher irradiance resulted in only slight cell damage in the superficial tumour layers. The xenon photocoagulator converted for thermotherapy was difficult to handle and manual focusing was not totally stable during the 1 minute exposure time. The rather short time interval between thermotherapy and enucleation, about 24 hours, in two eyes may have influenced the results since visualisation of heat induced lesions may depend on the time interval between thermotherapy and enucleation.

Eight tumours had TTT induced retinal lesions in the target area with a sharp demarcation between the damaged retina in and the normal retina outside the target area (Figs 1A,
2A, 3, 4A). The presence of subretinal exudate did not interfere with a thermotherapy effect in the tumour (Fig 3).

Ocular structures in and outside the radiation area remained unchanged owing to the low rate of absorption of radiation at $810 \mathrm{~nm}$ by clear ocular media of about $5 \% .{ }^{21}$ In three eyes the radiation beam from the handheld fibre had touched the iris at the pupillary margin and caused a localised subcapsular cataract; for clinical use the beam is stabilised by fixation of the fibre to a slit-lamp.

Scleral alterations induced by heat ${ }^{11}$ are not an impediment to clinical thermotherapy; the inner layers of the sclera became oedematous and sclerocytes disappeared but the lamellar structure of the scleral collagen remained intact. The sclera is fairly heat resistant since temperatures of $52.2^{\circ} \mathrm{C}$ for 45 minutes and $65^{\circ} \mathrm{C}$ for 1 minute did not cause significant damage. ${ }^{29-31}$

In one eye intrascleral tumour cells with a viable appearance were located only $36 \mu \mathrm{m}$ from a totally necrotic tumour (Fig 4B). The distance is too short to explain this viability by a decrease in temperature. Moreover, the heat was sufficient to destroy the sclerocytes in the inner scleral layers. If we assume that the tumour cells were located intravascularly, then their viability could be explained by a cooling effect of the blood circulation, as also observed in animal experiments. ${ }^{24}$

Since viable intrascleral tumour cells may be the source of tumour recurrences we usually combine TTT with ruthenium-106 brachytherapy. The two treatments, together coined as 'sandwich therapy', are complementary since the impact of the transpupillary infrared laser is maximal at the top of the tumour and that of the trans-scleral brachytherapy is maximal at its base (Fig 6).

This investigation was supported by grants of the 'Haags Oogheelkundig Fonds' and 'Stichting Blindenhulp'; Ed Barten assisted in the histological examination.

1 Haik BG, Jereb EB, Abramson DH, Ellsworth RM. Ophthalmic radiotherapy. In: lliff $\mathrm{N}$, ed. Complications in ophthalmic therapy. New York: Churchill Livingstone, 1983:449-85

2 Lommatzsch PK, Kirsch IH. ${ }^{106} \mathrm{Ru} /{ }^{106} \mathrm{Rh}$ plaque radiotherapy for malignant melanomas of the choroid. Doc Ophthalmol 1988;68:225-38.

$3 \mathrm{Kim} \mathrm{JH}$, Hahn EW, Tokita N. Combination hyperthermia and radiation therapy for cutaneous malignant melanoma. Cancer 1978;21:2143-8.

4 Overgaard J, Overgaard M. Hyperthermia as an adjuvant to radiotherapy in the treatment of malignant melanoma. Int $\mathcal{F}$ radiotherapy in the treatment of

5 Emami B, Perez CA, Konefal J, Pilepich MV, Leybovich L, Straube W, et al. Thermoradiotherapy of malignant Straube W, et al. Thermoradiotherapy of
melanoma. Int $\mathrm{f}$ Hyperthermia 1988;4:373-81.

melanoma. Int f Hyperthermia 1988;4:373-81.
6 Lagendijk JJW. Microwave applicator for hyperthermic 6 Lagendijk JJW. Microwave applicator for hyperthermic treatment of reting

1982;61:469-71.
7 Riedel KG. Hypertherme Therapieverfahren in Erganzung zur Strahlenbehandlung maligner intraokularer Tumoren. Klin Monatsbl Augenheilkd 1988;193:131-7.

8 Swift PS, Stauffer PR, Fries PD, Kaleta-Michaels S, Murray T, Sneed PK, et al. Microwave hyperthermia for choroidal melanoma in rabbits. Ophthalmol Vis Sci 1990;31:1754-60.

9 Finger PT. Microwave plaque thermoradiotherapy for choroidal melanoma. Br f Ophthalmol 1992;76:358-64.

10 Liggett PE, Pince KJ, Astrahan M, Rao N, Petrovich Z. Liged Purent field hyperthermia: Localized current field hyperthermia: effect on normal
ocular tissue. Int $\mathcal{F}$ Hyperthermia 1990;6:517-27.

11 Petrovich Z, Astrahan MA, Luxton G, Green R, Langholz B, Liggett PE. Episcleral plaque thermoradiotherapy in patients with choroidal melanoma. Int $\mathcal{F}$ Radiat Oncol Biol Phys 1992;23:599-603. 
12 Coleman DJ, Lizzi FL, Burgess SEP, Silverman RH, Smith $\mathrm{ME}$, Driller J, et al. Ultrasonic hyperthermia and radiation in the management of intraocular malignant melanoma. Am f Ophthalmol 1986;101:635-642.

13 Coleman DJ, Silverman RH, Iwamoto T, Lizzi FL, Rondeau MJ, Driller J, et al. Histopathologic effects of ultrasonically induced hyperthermia in intraocular malignant melanoma. Ophthalmology 1988;95:970-81.

14 Braakman $R$, van der Valk P, van Delft JL, de WolffRouendaal D, Oosterhuis JA. The effcts of ultrasonically induced hyperthermia on experimental tumors in the rabbit eye. Invest Ophthalmol Vis Sci 1989;30:835-44.

15 Mieler WF, Jaffe GJ, Steeves RA. Ferromagnetic hyperthermia and iodine-125 brachytherapy in the treatment of choroidal melanoma in a rabbit model. Arch Ophthalmol 1989;107:1524-8.

16 Overgaard J. Histopathologic effects of hyperthermia. In Storm FK, ed. Hyperthermia in cancer therapy. Boston: GK Hall, 1983:163-85. 7 Reinhold HS. Physiological effects of hyperthermia. Recent

8 Journee-de Korver JG, Verburg-van der Marel EH, Oosterhuis JA, van Best JA, de Wolff-Rouendaal D. Tumoricidal effect of hyperthermia by near infrared irradiation on pigmented hamster melanoma. Lasers Light Ophthalmol 1992;4:175-80

19 Oosterhuis JA, Journée-de Korver JG, Kakebeeke-Kemme HM, Bleeker JC. Transpupillary thermotherapy in choroidal melanomas. Arch Ophthalmol 1995;113:315-21.

20 Wheatley DN, Kerr C, Gregory DW. Heat-induced damage to HeLa-S3 cells: correlation of viability, permeability, osmosensitivity, phase-contrast light-, scanning electronand transmission electron-microscopical findings. Int $\mathcal{F}$ Hyperthermia 1989;5:145-62.

21 Geeraets WJ, Berry ER. Ocular spectral characteristics as related to hazards from lasers and other light sources. $A m \mathcal{F}$ Ophthalmol 1968;66:15-20.
22 Journée-de Korver JG, Oosterhuis JA, van Best JA, Fakkel J. Xenon arch photocoagulator used for transpupillary hyperthermia. Doc Ophthalmol 1991;78:183-7.

23 Nuijs-Beems EM, Oosterhuis JA, Verburg-van der Marel $\mathrm{EH}$, de Wolff-Rouendaal D, van Delft JL, van Best JA. Tumor destruction by intermediate level hyperthermia. Curr Eye Res 1990;9:771-80.

24 Journée-de Korver JG, Oosterhuis JA, Vrensen GFJM. Light and electron microscopic findings on experimental melanomas after hyperthermia at $50^{\circ} \mathrm{C}$. Melanoma Res 1995;5:393-402.

25 Noyori KS, Campbell CJ, Rittler MC. Ocular thermal effects produced by photocoagulation. Arch Ophthalmol 1963;70:817-22.

26 Priebe LA, Cain CP, Welch AJ. Temperature rise required for production of minimal lesions in the Macaca mulatta retina. Am f Ophthalmol 1975;79:405-13.

27 Bollemeyer JG, Lagendijk JJW, van Best JA, de Leeuw AAC, van Delft JL, de Wolff-Rouendaal D, et al. Effects of microwave-induced hyperthermia on the anterior segment of healthy rabbit eyes. Graefes Arch Clin Exp Ophthalmol 1989;227:271-6.

28 Foster JBT, DeNatale A, Dotti LB. Determination of plasma fibrinogen by means of centrifugation after heating. $A m \mathcal{F}$ Clin Pathol 1959;31:42-5.

29 Burgess SEP, Chang S, Svitra PP, Driller J, Lizzi FL, Coleman DJ. Effect of hyperthermia on experimental choroidal melanoma. Br f Ophthalmol 1985;69:854-60.

30 Finger PT, Packer S, Paglione RW, Gatz JF, Ho TK, Bosworth JL. Thermoradiotherapy of choroidal melanoma: a clinical experience. Ophthalmology 1989;96:1384-8.

31 Finger PT, Svitra PP, McCormick SA, Presser A. Microwave diathermy of the retina and choroid. Arch Ophthalmol 1993;11:254-8. 